\title{
Accountability for Motorized Vehicle Owners Used By Children in Traffic Accidents (Case Study on Supreme Court Decision Number 1029 K / Pid.Sus / 2015)
}

\begin{abstract}
Yanto Risdianto ${ }^{1}$ and Lathifah Hanim ${ }^{2}$
Abstract: The formulation of the problem in this study are: 1) parts of criminal liability of the owner of a motorized vehicle whose vehicle was used in a traffic accident Case Study of the Decision of the Supreme Court of the Republic of Indonesia Number $1029 \mathrm{~K} /$ Pid.Sus / 2015? And 2) how is the legal protection of children as perpetrators in traffic accidents Case Study of the Supreme Court's Decision No. 1029 K / Pid.Sus / 2015?

The method used by researchers is juridical sociological legal approach and the specifications in this study are descriptive analytical. The sources and types of data in this study are primary data obtained from interview field studies. And secondary data obtained from literature studies relating to the theory of criminal liability and legal protection.

Based on the results of that study The criminal liability of the owner of a motorized vehicle whose vehicle is used in a traffic accident by a child is not held accountable even if only as an inclusion, the child who commits a traffic violation or a traffic crime is the sole offender, even if the motorized vehicle used by permission of an adult, both his parents or other vehicle owners. The legal protection of children as perpetrators in traffic accidents has not been fulfilled as in the Supreme Court Decree No. 1029 K / Pid.Sus / 2015, the vehicle owner who surrendered his vehicle (car) was only made a witness in a traffic accident that resulted in a victim died, and the child became the sole culprit.

Keywords: Liability; Criminal; Motorized Vehicles; Children.
\end{abstract}

\section{Introduction}

Road Traffic and Transport has a strategic role in supporting national development and integrity as part of efforts to advance public welfare as mandated by the Constitution of the Republic of Indonesia 1945. Traffic and Road Transportation as part of the national transportation system must develop their potential and role to realize security, safety, order and smoothness of traffic and Road Transportation in order to support economic development and regional development

The Road Traffic and Transportation Act No. 22/2009 in Article 1 paragraph (1) says that: Paragraph (1). Road Traffic and Transport is a united system consisting of Traffic, Road Transportation, Road Traffic and Road Transportation Networks, Vehicles, Drivers, Road Users, and Its Management ${ }^{3}$.

News about traffic accidents, no longer strange to hear, both through print and electronic media, as if to show that traffic accidents often occur. Some problems appear to be a factor causing the number of traffic accidents that are quite high,

\footnotetext{
${ }^{1}$ Student of Master of Law, Universitas Islam Sultan Agung Semarang and Indonesian Police, email: risdianto_008@yahoo.co.id

${ }^{2}$ Lecturer of Master of Law, Sultan Agung Islamic University (UNISSULA), Semarang

${ }^{3}$ Act No. 22 Of 2009 On Road Traffic and Transportation.
} 
including human factors, human factors, such as vehicle health, road damage, overloading roads, and other supporting facilities contributing to traffic accidents.

Many traffic accidents occur dominated by underage actors or children. This is of course a violation that needs to be accounted for because at such an age a right or permission to drive cannot be given. In addition, at this age the state of the soul and mind is still very unstable, therefore motorists who are still children often have accidents because of negligence just call it by speeding on the road.

The issue of legal protection for children is one way to protect the future shoots of the nation. Legal protection for children concerns all applicable legal rules. This protection is necessary because children are part of the community who have physical and mental limitations. Therefore, children need special protection and care. ${ }^{4}$ Child protection is a business that carries out conditions where every child can exercise rights and obligations. The protection of children is an embodiment of justice in a society.

In this inclusion problem there is a psychic (or intellectual) and material (physical) perpetrator of a criminal offense. Crimes committed by two or more people, with the record; not every activity of each of these people raises the same responsibility for these people. Inclusion allows a participant to be punished for his actions, even if the act only fulfills a portion of the formulation of a criminal offense, or the participant only provides donations or assistance in the form of certain acts to others to carry out his criminal acts 5 .

Because the relationship of each participant to the crime can take various forms, then the teaching of this inclusion rests on "determining the accountability" of the participants to the crime that has been committed ${ }^{6}$. Thus the doctrine of inclusion or participation, questions the role or relationship of each participant in the implementation of a crime, a contribution or what is given by each participant, so that the crime can be carried out / resolved (voltooid), as well as the accountability for the contribution / that help.

The phenomenon of children who drive motorized vehicles both two-wheeled and four-wheeled, occurs due to various children, the existence of stealing and without the knowledge of their parents driving a motorized vehicle on the highway, but instead there are also children who drive motorized vehicles to school because of and with the permission of his parents, even encouraged by the parents to save transportation costs to school. Even though the school does not allow students to bring motorized vehicles, the prohibition does not eliminate students not going to school by driving a motorized vehicle, for example, in SMAN 2 of Cirebon City and students whose schools are close to Gunung Sari Market which has large parking lots, children the school did not bring a vehicle and parked its motorized vehicle in the school's parking lot,

Based on the background of the problem above, then the problem can be formulated as follows: What is the criminal liability of the owner of a motorized vehicle whose vehicle was used by Children in a traffic accident? Case Study of the Supreme Court's Decision No. 1029 K / Pid.Sus / 2015?; How is the legal protection of children as

\footnotetext{
${ }^{4}$ Harkristuti Harkrisnowo, 2002, Menelaah Konsep Sistem Peradilan Pidana Terpadu (dalam konteks Indonesia), Medan, p. 3

${ }^{5}$ Abdul Salam Siku, 2015, HukumPidana II. Pustaka Rabbani Indonesia, Ciputat, p. 44

${ }^{6}$ Teguh Prasetyo, Jakarta, Hukum Pidana, PT RajaGrafindo Persada, Jakarta, p. 204.
} 
perpetrators in traffic accidents Case Study of the Supreme Court's Decision No. 1029 K / Pid.Sus / 2015?

\section{Research Methods}

The method used by researchers is juridical sociological legal approach and the specifications in this study are descriptive analytical. The sources and types of data in this study are primary data obtained from interview field studies. And secondary data obtained from literature studies relating to the theory of criminal liability and legal protection.

\section{Results and Discussion}

\subsection{Criminal Liability Of The Owner Of A Motorized Vehicle Whose Vehicle Was Used By Children In A Traffic Accident Case Study Of The Decision Of The Supreme Court Of The Republic Of Indonesia Number 1029 K / Pid.Sus / 2015}

Juvenile Justice as a medium for criminal liability committed by children is different from the judiciary in general given the special privileges that children have. Treatment of children needs to be distinguished because at that time the child's blood, body and soul are undergoing development. Thus, it can be said that the child is in an unstable state. So there is something different when we talk about children. The child is not an adult, so he cannot be compared to the miniature of an adult, because it must be given a different treatment, also because the child itself is in its infancy and must have protection from the start. That is what causes the difference in the treatment of children.

Traffic accidents can be classified as minor, moderate and severe traffic accidents. Based on the classification, in terms of the effects caused by the target or object is goods in the form of motorized vehicles and people as motorized vehicle drivers. As a result of traffic accidents where the object or object is damaged is a motorized vehicle, while the target or object of a person is a motorized vehicle injury or illness, both minor injuries, severe injuries, and even death.

Decision of the Supreme Court of the Republic of Indonesia Nomo 1029 K / Pid.Sus / 2015 obtained from the Director of the Supreme Court Decision on the website https://putusan.mahkamahagung.go.id/. Furthermore, the decision is made by the authors of the analysis as described in the following section.

The Decision of the Supreme Court of the Republic of Indonesia Nomo 1029 K / Pid.Sus / 2015 dated April 23, 2015 is essentially: Refusing the Cassation Request for Cassation Request: The Public Prosecutor to the Prosecutor / Public Prosecutor at the Tangerang District Attorney; Charge the Defendant to pay the court fee at the cassation level of Rp. 2,500.00 (two thousand and five hundred rupiah);

The Supreme Court believes:

- Whereas the for the cassation of the Petitioner / Public Prosecutor's Appeal cannot be appealed justified because Judex Facti is not wrong to apply the law in prosecuting Defendant;

- That the Judex Facti ruling of the Banten High Court Number: 12 / Pid.SusAnak / 2014 / PT.BTN dated January 6, 2015 reinforces the decision Tangerang District 
Court Number: 14 / Pid.Sus-Anak / 2014 / PN.TNG. the date November 26, 2014 which stated Defendant DEWI RISTI DIRMAN binti DIRMAN was proven legally and convincingly guilty of committing a crime "Driving a motorized vehicle because of its negligence resulted traffic accidents and other people die "and therefore the Defendant is sentenced to imprichildrenment: 1 (one) year, made based on correct legal considerations;

Decision of the Supreme Court of the Republic of Indonesia Nomo $1029 \mathrm{~K} /$ Pid.Sus / 2015 the author agrees with the decision of the Supreme Court of the Republic of Indonesia. In this traffic accident case, it seems clear that the perpetrators of the crime are children who are not yet entitled to drive motorized vehicles such as cars, because they are not old enough and cannot obtain a driving license (SIM) because they have not reached 17 (seventeen) years as the age requirement to get a SIM. ${ }^{7}$

The high number of traffic accident cases should be a common concern, especially if the perpetrators of traffic violations are minors. Refer to Act No. 22 of 2009 On Traffic and Road Transportation (UU LLAJ), the definition of a driver based on Article 1 number 23 of the LLAJ Law is a person who drives a motorized vehicle on a road that has a Driving License (SIM). While the mandatory requirements for drivers based on Article 77 paragraph (1) of the LLAJ Law are having a SIM in accordance with the type of motorized vehicle being driven. As is known, the minimum age of 17 years is the age requirement to get a SIM, which is SIM A, SIM C and SIM D in accordance with Article 81 paragraph (2) letter a of the LLAJ Law. Article 81 Paragraph 1 of the LLAJ Law also affirms that a person can obtain a SIM if it meets the age, administrative, health ${ }^{8}$.

Based on the description above, according to the author that the owner of the vehicle, whether parents or not, allows, even permits children who do not have a SIM and is not even entitled to get a SIM to drive a motorized vehicle, whether motorbike or car, should have criminal liability be minimized as inclusion.

The criminal liability of the owner of a motorized vehicle whose vehicle is used in a traffic accident by a child is not held accountable even if only as an inclusion, the child who commits a traffic violation or a traffic crime is the sole offender, even if the motorized vehicle used by permission of an adult, both his parents or other vehicle owners.

\subsection{Legal Protection Of Children As Actors In Traffic Accidents Case Study Of The Supreme Court's Decision No. 1029 K / Pid.Sus / 2015}

The issue of legal protection for children is one way to protect the future shoots of the nation. Legal protection for children concerns all applicable legal rules. This protection is necessary because children are part of the community who have physical and mental limitations. Therefore, children need special protection and care. ${ }^{9}$ Child protection is a

\footnotetext{
${ }^{7}$ The results of an interview with Sumardjiatmo, $\mathrm{SH}$., $\mathrm{MH}$, as the Children Cassation Judge, on the steps of January 22, 2020, at 13.45 WIB

${ }^{8}$ Imas Sholihah, Menyoroti Maraknya Pengendara Motor Di Bawah Umur, Jurnal Rechts Vinding On Line, Media Pembinaan Hukum Nasional, 02 August 2016, p. 1

${ }^{9}$ Harkristuti Harkrisnowo, 2002, Menelaah Konsep Sistem Peradilan Pidana Terpadu (dalam konteks Indonesia), Medan, p. 3
} 
business that carries out conditions where every child can exercise rights and obligations. The protection of children is an embodiment of justice in a society.

Transportation access on the road both as a driver and passenger is no longer only owned by those in the adult category. Children born and thriving in the era of transportation and rapidly advancing technology no longer only act as vehicle passengers but are already active drivers of these vehicles. It will not be a problem if done if it meets the criteria referred to as the driver. In accordance with the mandate of the law. ${ }^{10}$ That which can then be said as drivers are those who already have a driving license. Whereas to get a driver's license are those who are at least 17 years old Attempts by the Public Prosecutor to Appeal to Cassation to request a criminal decision handed down to a DEWI Child RISTI DIRMAN in Decision of the Supreme Court of the Republic of Indonesia Nomo 1029 K / Pid.Sus / 2015 proves that the Prosecutor General is more concerned to convict a child with a higher crime than to ensnare a vehicle owner (car) who let the child drive a car without a SIM even not yet entitled to get a SIM . This situation is not a manifestation of the existence of justice in a society, especially against children. ${ }^{11}$

Overcoming the number of underage motorbikes is a common concern and responsibility, the community must actively participate in supporting traffic law enforcement by providing information and input to the police related to traffic and road transportation issues including violations committed by minors. Social media and online applications can be a means of active participation of the people who are directly connected to the police. School policies and family attention are also needed in securing child discipline and understanding of driving by having a SIM at the minimum age of 17 years ${ }^{12}$.

The parents buy motorized vehicles for their children both for gifts and to save expenses, especially transport to school, so parents forget the dangers of children driving motorized vehicles, meaning that if a child commits a traffic violation his parents should also participate in committing the violation, because parents know how old their children are when given a motorized vehicle. Thus, UULLAJR should make parents who give motorized vehicles to children who are not yet entitled to get a SIM can be held liable for criminal liability, because they consciously let even possibly order their children to commit traffic violations.

Protection of children is carried out in all aspects of life, including in this case is in juvenile criminal justice. Placement of the word "child" in juvenile justice shows the limits on cases handled by the judiciary, namely cases of children. In juvenile criminal justice, there are several interrelated elements, namely: Child investigator, Child Prosecutor, Child Judge, and Child Correctional Officer. Fair Child Criminal Justice provides protection for children, both as suspects, defendants, and as convicts / convicts. The Committee on the Rights of the Child emphasized that the juvenile justice

\footnotetext{
${ }^{10}$ Article 1 Item 23 of Act No. 22 Of 2009 On Road Traffic and Transportation

${ }^{11}$ The results of an interview with Sumardjiatmo, $\mathrm{SH}$., $\mathrm{MH}$, as the Children Cassation Judge, on the steps of January 22, 2020, at 13.45 WIB

${ }^{12}$ Imas Sholihah, Op.cit., p. 5-6.
} 
system is a criminal justice system that is separated specifically for children so that children can enjoy legal protection (due process) and the inherent human rights. ${ }^{13}$

The legal protection of children as perpetrators in traffic accidents has not been fulfilled as in the Supreme Court Decree No. 1029 K / Pid.Sus / 2015, the vehicle owner who surrendered his vehicle (car) was only made a witness in a traffic accident that resulted in a victim died, and the child became the sole perpetrator

\section{Closing}

\subsection{Conclusion}

- The criminal liability of the owner of a motorized vehicle whose vehicle is used in a traffic accident by a child is not held accountable even if only as an inclusion, the child who commits a traffic violation or a traffic crime is the sole offender, even if the motorized vehicle used by permission of an adult, both his parents or other vehicle owners.

- The legal protection of children as perpetrators in traffic accidents has not been fulfilled as in the Supreme Court Decree No. 1029 K / Pid.Sus / 2015, the vehicle owner who surrendered his vehicle (car) was only made a witness in a traffic accident that resulted in a victim died, and the child became the sole culprit.

\subsection{Suggestion}

- Adults who hand over motorized vehicles to children who do not yet have and / or are entitled to have a SIM should be asked for criminal liability in the form of participation, because the adult owner of the vehicle already knows that to be able to drive a motorized vehicle must be equipped with a SIM.

- Amendments to the Traffic Law and Road Traffic Rules in the future should be for vehicle owners who surrender their vehicles to be driven by people who do not have the right to not even get a SIM with a criminal liability for inclusion, and a SIM must be a condition for someone to be able to purchase a motorized vehicle.

\section{References}

[1] Abdul Salam Siku, 2015, HukumPidana II. Pustaka Rabbani Indonesia, Ciputat,

[2] Harkristuti Harkrisnowo, Menelaah Konsep Sistem Peradilan Pidana Terpadu (dalam konteks Indonesia). (Medan: 2002)

[3] Imas Sholihah, Menyoroti Maraknya Pengendara Motor Di Bawah Umur, Jurnal Rechts Vinding On Line, Media Pembinaan Hukum Nasional, 02 Agustus 2016

[4] Lilik Mulyadi, Pengadilan Anak di Indonesia Teori, Praktik, dan Permasalahannya, Bandung, Penerbit Mandar Maju, 2005

[5] Article 1 Item 23 of Act No. 22 Of 2009 On Road Traffic and Transportation

[6] Teguh Prasetyo, Jakarta, Hukum Pidana, PT RajaGrafindo Persada, Jakarta, Jakarta

[7] Act No. 22 Of 2009 On Road Traffic and Transportation.

\footnotetext{
${ }^{13}$ Lilik Mulyadi, Juvenile Court in Indonesia Theory, Practice, and Problems, Bandung, Mandar Maju Publisher, 2005. pp. 8-9
} 